\title{
A molecular docking study of SARS-CoV-2 main protease against phytochemicals of Siddha Medicinal herb Vilvam (Aegle marmelos)
}

\author{
Research Article
}

\section{Nagappan A G1*, Krishnaveni $\mathbf{M}^{2}$, Monika $\mathrm{T}^{3}$, Thillaivanan $\mathrm{S}^{4}$, Selvamoorthy $\mathrm{G}^{5}$}

1. Assistant Medical Officer (Siddha), Department of Indian Medicine and Homeopathy, Government of Tamilnadu.

2. Professor \& Head of the Department, Gunapadam branch, Government Siddha Medical College, Chennai.

3. Siddha Consultant, Abinaya Siddha Clinic, Harur, Tamilnadu.

4. Assistant Medical Officer (Siddha), Department of Indian Medicine and Homeopathy, Government of Tamilnadu.

5. District Siddha Medical Officer, Department of Indian Medicine and Homeopathy, Government of Tamilnadu.

\begin{abstract}
Background: In December of 2019, mysterious pneumonia was reported. A novel coronavirus (nCoV) was identified as the causative agent for this pneumonia; it is now known as coronavirus 2 . This pandemic has caused widespread alarm around the world. Now, countries around the world are preparing for the third and fourth waves of COVID-19. Objective: This research aims to conduct In Silico computational studies of phytoconstituents in leaf extracts of the Siddha medicinal herb Aegle marmelos (Vilvam), which are commonly used in the treatment of viral fever and respiratory infectious diseases and may be effective against the current pandemic novel coronavirus disease. Methodology: In Silico molecular docking analysis was performed for all the active compounds present in the herb Aegle marmelos (Vilvam) with potential targets SARS-CoV-2 Main Protease (PDB ID: 7JQ5). The ligand structures were prepared and optimized by AutoDockTools. The active sites docking study was performed using Autodock Vina for all the compounds. The inhibitor compound MPI8 bound inSARS-CoV-2 main protease ProteinLigand complex (PDB ID: 7JQ5) is considered as the reference inhibitor molecule of this study. Results: Molecular docking of the 14 bioactive phytochemicals compounds from Aegle marmelos leaves carried out towards the active site of SARS-CoV-2 Main Protease protein (PDB ID: 7JQ5). The interactions of these compounds were comparatively analyzed with the reference inhibitor MPI8 bound inSARS-CoV-2 Main Protease protein-ligand complex (PDB ID: 7JQ5). These phytochemicals exhibited effective molecular interactions with the active residues enumerating their differential inhibition potency. Conclusion: Further research and clinical trials are needed whether this herb can be implemented to effectively treat and manage COVID-19.
\end{abstract}

Key Words: Molecular docking, Siddha medicine, Ayush Medicine, Network pharmacology, Indian Traditional Medicine.

\section{Introduction}

COVID-19 is also named SARS-CoV-2 which is a dreadful disease heading towards the world at this moment. This virus belongs to the family Coronaviridae. The family Coronaviridae has two genera-Coranavirus and Torovirus. They possess 12 and 2 species respectively. Only two species of genus coronavirus, human coronavirus $229 \mathrm{E}$ and the human coronavirus $0 \mathrm{C} 43$ cause respiratory and gastrointestinal infections (1). By infecting bronchial epithelial cells, pneumocytes and upper respiratory tract cells in humans, SARS-CoV, MERS-CoV and SARS-CoV-2 infections can develop into severe, life-threatening respiratory pathologies and lung injuries for which no specific prophylactic or therapeutic treatment has been

* Corresponding Author:

Nagappan A G

Assistant Medical Officer (Siddha),

Department of Indian Medicine and Homeopathy,

Govt of Tamilnadu,

India

Email Id: dragnagappan@gmail.com approved to date. (2). On 31st December 2019, 27 cases of pneumonia of unknown aetiology were recognized in Wuhan City, in China. The causative organism was detected from the throat swab led by the Chinese Centre for Disease Control and Prevention (CCDC) on $7^{\text {th }}$ January 2020 and was along these lines named Severe Acute Respiratory Syndrome Coronavirus (SARSCoV-2) (3). The World Health Organization (WHO) named this entity COVID-19. On 30th January 2020, the WHO proclaimed the Chinese episode of COVID-19 to be a Public Health Emergency of International Concern representing a high hazard to nations with weak wellbeing frameworks (4). The first case of Covid-19 was reported on 27th Jan 2020 in India. The second wave resulted from approximately one lakh positive cases daily. The first case of the COVID-19 in the Indian state of Tamil Nadu was reported on 7 March 2020. As of July 29, 2021, exactly 4, 22,022 patients were died in India, with Maharashtra reported the highest rate of deaths of $1,32,145$. As of July 29, 2021, Tamilnadu had 2,55,3805 confirmed cases (5). Majority of the proposed COVID-19 vaccines requires a follow up dose with multiple shots. Additionally, SARS- CoV-2 has shown capacity to 
Nagappan A G et.al., A molecular docking study of SARS-CoV-2 main protease against phytochemicals of Vilvam

mutate and render certain vaccines ineffective. These challenges may be overcome by the discovery of a potent antiviral compound (6). To prevent, manage, and treat this devastating disease, it is a period to come back to our traditional Siddha system of medicine.

Siddha medicines have been used effectively by human's traditional civilization over several centuries for treating different kinds of diseases and can be effectively recommended to target the host response, like Kaba Sura Kudineer during influenza outbreaks (7). The Siddha medical system is a well-known ancient Indian medicinal system. It plays a significant role in the treatment of Covid-19 disease, particularly in Tamil Nadu. The Siddha system of medicine considers the body as a conglomeration of three dosham known as Vatham (Wind), Pitham (Fire), and Kabam (Water), corresponding to the three elements of the universe. Equilibrium between the three dosham is necessary to maintain perfect health. Any derangement in the synergic action of these dosham transforms the body as a fertile ground to pop up any infection (8). Since Siddha system of medicine deals with the root cause of diseases, Kaba Suram is said to occur due to the aggravated humour of Kabam much more than its normalcy, facilitating a favourable environment for any respiratory infection (9). Many traditional herbs have been reported to possess potent anti-viral properties (10) and can aid in the reduction of Kabam.

As per the Siddha literature, Aegle marmelos (Vilvam) is used to treat various kinds of fever and viral infections (11). Some of the pharmacological studies reveal the Antipyretic and Analgesic properties of Aegle marmelos (Vilvam) (12). Some studies confer Aegle marmelos (Vilvam) numerous pharmacological actions associated to respiratory illnesses, including antiviral activity $(13,14)$, antipyretic activity $(15,16)$, antiinflammatory activity (17), anti-histaminic effect, and anti-asthmatic activity (18).

Many analytical studies have been performed on these compositions and active compounds with their structure have been identified. The COVID-19 pathogen, SARS-CoV-2, requires its main protease (SC2M Pro) to digest two of its translated long polypeptides to form several mature proteins that are essential for viral replication and pathogenesis. Inhibition of this vital proteolytic process is effective in preventing the virus from replicating in infected cells and therefore provides a potential COVID-19 treatment option. Although we have yet to understand SARSCoV-2 biology and COVID-19 pathogenesis, previous studies of SARS-CoV-1 have established that activity of

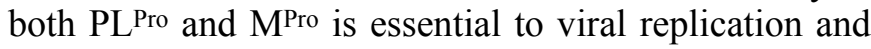
pathogenesis. Of the two proteases, Mro processes 12 out of the total $15 \mathrm{Nsps}$; inhibition of this enzyme is anticipated to have more significant impacts on viral biology than that of PLPro. Therefore, small-molecule medicines that potently inhibit SARS-CoV-2 MPro (SC2M ${ }^{\text {Pro }) ~(P D B ~ I D: ~ 7 J Q 5) ~(19), ~ a r e ~ p o t e n t i a l l y ~}$ effective treatment options for COVID-19. Molecular docking studies can be performed to determine active natural compounds with inhibitory effects against both the protein involved in coronavirus disease pathogenesis.

\section{Materials and methods Protein-ligand docking Protein preparation}

The crystal structure of the SARS-CoV-2 Main Protease protein-ligand complex (PDB ID: 7JQ5) was obtained from RSCB Protein Data Bank. The 3D protein structures were optimized and prepared using AutoDockToolsv1.5.6. (20). The inhibitor MPI8 bound inSARS-CoV-2 Main Protease protein-ligand complex (PDB ID: 7JQ5) is considered as the reference inhibitor for comparison in this study.

\section{Ligand preparation}

The bioactive molecules constituents in the leaf extract of the medicinal herb Aegle marmelos (Vilvam) were reported as Methyldodecanol, Carene, AlphaAmyrin, Alpha Cubebene, Cinnamamide, D-Limonene, Gamma- Sitosterol, Heneicosane, Humulene, Isoledene, Linalyl Acetate, Loliolide, O-Xylene, Tridecane. Hence, the $3 \mathrm{D}$ structural coordinates of these 14 bioactive phytochemicals obtained from PubChem were selected for docking studies. These ligand structures were further optimized and prepared using AutoDockToolsv1.5.6. (21).

\section{Molecular Docking}

Docking was performed with AutodockVina v112 (22), a prevalent molecular screening tool for predicting/identifying the approximate binding energy of each ligand with the target proteins. The docking parameters were optimized with the grid box centered on the MPI8 Inhibitor at the active site of the protein. Then, Docking analysis was carried out individually for each compound at the active ligand-binding site (MPI8 Inhibitor bound site) of SARS-CoV-2 Main Protease protein (PDB ID: 7JQ5) and the binding energies of each ligand found. All graphical presentations of the docked complexes were illustrated using Discovery studio visualizer v2.5 (BIOVIA, San Diego, CA, USA)

\section{ADME properties prediction}

The ADME (absorption, distribution, metabolism, excretion) properties of above mentioned natural compounds were predicted using SwissADME an online tool for ADME prediction (23). The bioactivity score of the best compound was predicted using mol inspiration (24).

\section{Results}

Molecular docking of the 14 bioactive phytochemical compounds from Aegle marmelos leaves was carried out towardsSARS-CoV-2 Main Protease protein (PDB ID: 7JQ5) to identify their molecular interactions mediating their inhibition potency. The inhibitor compound MPI8 bound in the SARS-CoV-2 Main Protease protein-ligand complex (PDB ID: 7JQ5) is considered as the reference inhibitor molecule in this study. 
Table 1: Shows the bioactive compounds from Aegle marmelos (Vilvam) leaves

\begin{tabular}{|c|c|c|c|c|c|}
\hline SI.No & Pubchem ID & Compound Name & Molecular weight & Molecular formula & \\
\hline 1 & 33865 & 11-Methyldodecanol & $200.36 \mathrm{~g} / \mathrm{mol}$ & $\mathrm{C}_{13} \mathrm{H}_{28} \mathrm{O}$ & \\
\hline 2 & 26049 & 3-Carene & $136.23 \mathrm{~g} / \mathrm{mol}$ & $\mathrm{C}_{10} \mathrm{H}_{16}$ & \\
\hline 3 & 73170 & Alpha-Amyrin & $426.7 \mathrm{~g} / \mathrm{mol}$ & $\mathrm{C}_{30} \mathrm{H}_{50} \mathrm{O}$ & \\
\hline 4 & 86609 & AlphaCubebene & $204.35 \mathrm{~g} / \mathrm{mol}$ & $\mathrm{C}_{15} \mathrm{H}_{24}$ & \\
\hline 5 & 5273472 & Cinnamamide, & $147.17 \mathrm{~g} / \mathrm{mol}$ & $\mathrm{C}_{9} \mathrm{H}_{9} \mathrm{NO}$ & \\
\hline 6 & 440917 & D-Limonene & $136.23 \mathrm{~g} / \mathrm{mol}$ & $\mathrm{C}_{10} \mathrm{H}_{16}$ & \\
\hline 7 & 457801 & Gamma-Sitosterol & $414.7 \mathrm{~g} / \mathrm{mol}$ & $\mathrm{C}_{29} \mathrm{H}_{50} \mathrm{O}$ & \\
\hline
\end{tabular}




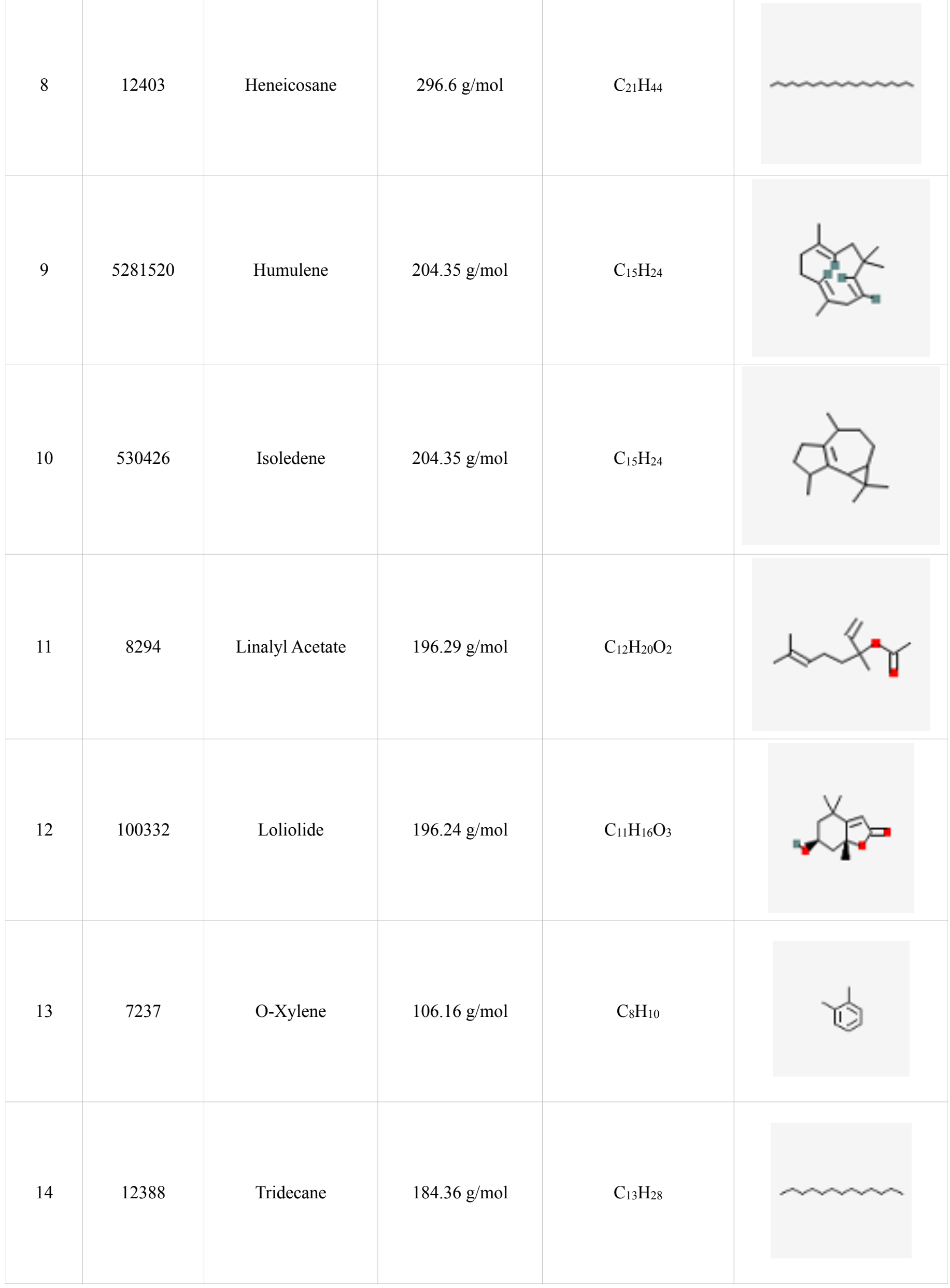


Figure-I: The 3D Structure of SARS-CoV-2 Main Protease protein-ligand complex (PDB ID: 7JQ5) bound with the MPI8 Inhibitor

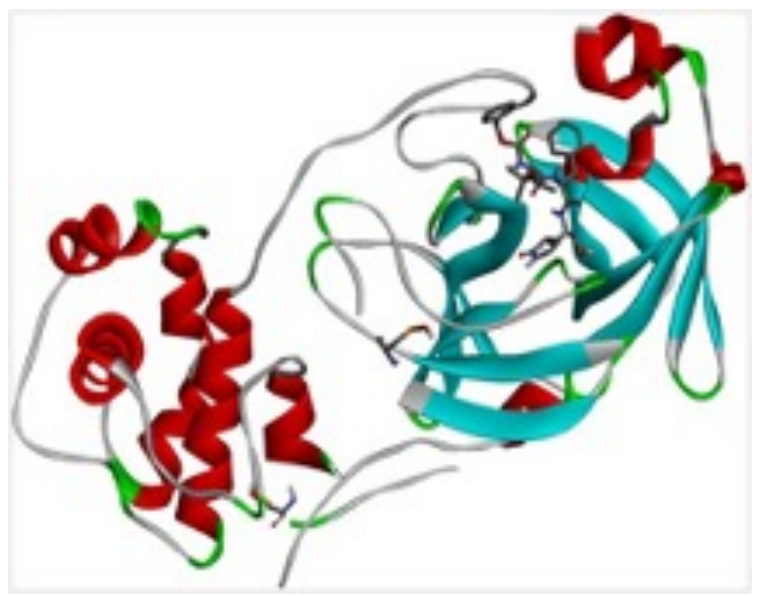

This demonstrates that the docking prediction is quite close to the actual bound complex, demonstrating the reference compound MPI8 inhibitor's interactions with the SARS-CoV-2 Main Protease.

The bonded interactions were found with Phe140, Glu166, Gly143, Ser144, Cys145 through conventional $\mathrm{H}$-bonds and the non-bonded interactions with Tyr54, Asp187, Arg188, Leu167, Gln192, His164, His172, Leu141, Asn142, Met165 through Van der Waals interactions and His41, Met49 through Alkyl interactions. The inhibition potency of the compounds was analyzed based on their Binding energy profile and they are bonded and non-bonded interactions with the active site residues. The predicted docking score is represented as B.E which depicts the approximate binding property of these ligands with the protein is given in Table- II.

Table- II: Shows binding property of these ligands with the protein

\begin{tabular}{|l|c|c|}
\hline \multicolumn{1}{|c|}{ Ligands } & ID & $\begin{array}{c}\text { Binding Energy } \\
\text { (Kcal/mol) }\end{array}$ \\
\hline MPI8 - inhibitor & MPI8 & -7.7 \\
\hline Alpha-Amyrin & 73170 & -7.6 \\
\hline Gamma-Sitosterol & 457801 & -6.7 \\
\hline AlphaCubebene & 86609 & -5.7 \\
\hline Loliolide & 100332 & -5.7 \\
\hline Isoledene & 530426 & -5.4 \\
\hline 3-Carene & 26049 & -5.1 \\
\hline Humulene & 5281520 & -5.7 \\
\hline Cinnamamide & 5273472 & -5.1 \\
\hline Linalyl Acetate & 8294 & -4.8 \\
\hline D-Limonene & 440917 & -4.7 \\
\hline Heneicosane & 12403 & -4.5 \\
\hline 11-Methyldodecanol & 33865 & -4.4 \\
\hline O-Xylene & 7237 & -4.1 \\
\hline Tridecane & 12388 & -3.7 \\
\hline
\end{tabular}

Based on their Binding profile, the top 5 phytochemical molecules Alpha-Amyrin, Gamma Sitosterol, Alpha Cubebene, Loliolide and Humulene were revealed to have a comparatively better B.E. than the MPI8 inhibitor. As a result, their molecular interactions were evaluated to see how effective they were at inhibiting MPI8. Hence, their molecular

Figure-II: shows the docked conformation of MPI8 inhibitor with B.E of $-7.7 \mathrm{Kcal} / \mathrm{mol}$ superimposed with the original protein-ligand complex crystal conformation (7JQ5)

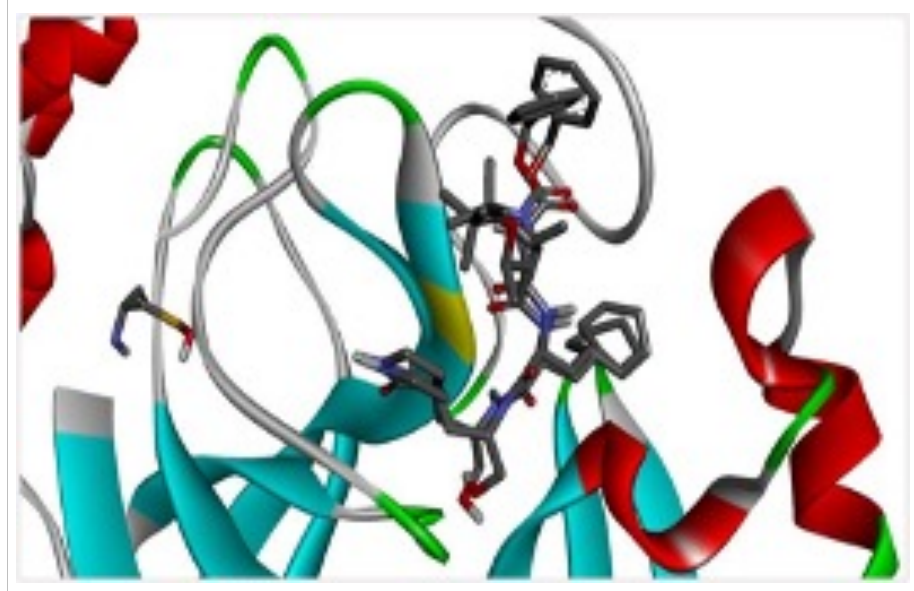

interactions were analyzed to evaluate their inhibition efficacy in comparison to MPI8.

Figure-III - The bonded and non-bonded interactions of the MPI8 inhibitor are represented in the 2D ligand interactions profile

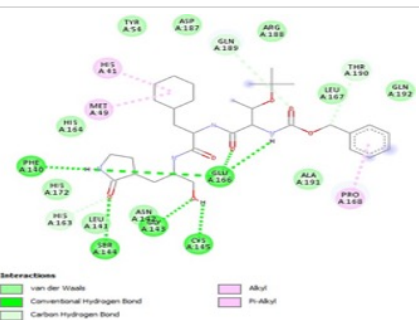

Figure-V: The bonded and non-bonded interactions of

Gamma-Sitosterol are

represented in the $2 \mathrm{D}$

ligand interactions profile

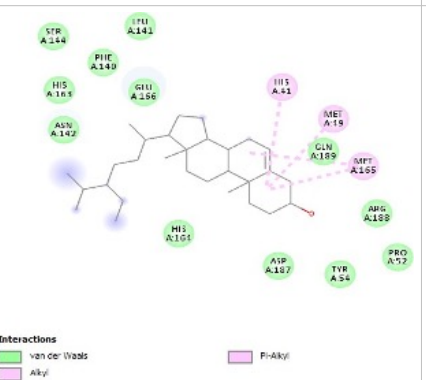

Figure-VII: The bonded and non-bonded

interactions of Loliolide are represented in the $2 \mathrm{D}$

ligand interactions profile

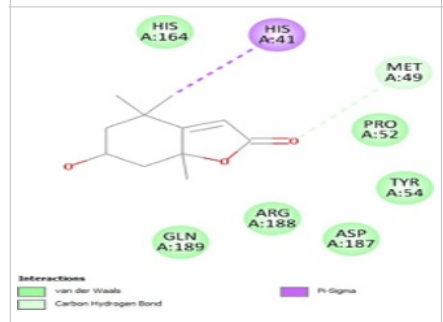

Figure-IV: The bonded and non-bonded interactions of Alpha-Amyrin are represented in the $2 D$ ligand interactions profile

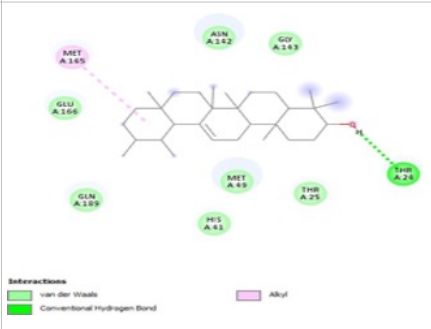

Figure-VI: The bonded and non-bonded interactions of Alpha Cubebene are represented in the $2 \mathrm{D}$ ligand interactions profile

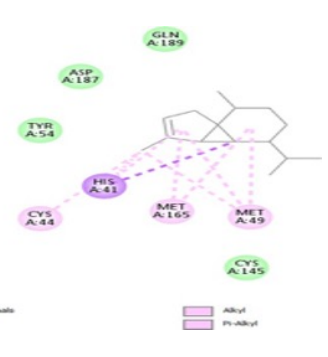

Figure-VIII: The bonded and non-bonded interactions of Humulene are represented in the $2 \mathrm{D}$ ligand interactions profile

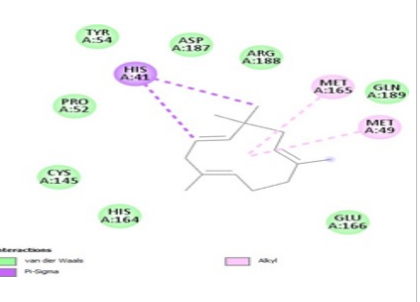


Nagappan A G et.al., A molecular docking study of SARS-CoV-2 main protease against phytochemicals of Vilvam

Table - III: The top 5 phytochemicals of the herb with better binding energy and bonded, non-bonded interactions are summarized

\begin{tabular}{|c|c|c|c|}
\hline Ligands & $\begin{array}{l}\text { Binding } \\
\text { Energy } \\
\text { (Kcal/ } \\
\text { mol) }\end{array}$ & $\begin{array}{l}\text { Bonded } \\
\text { Interact } \\
\text { ions } \\
\text { H-Bond }\end{array}$ & $\begin{array}{c}\text { Non bonded } \\
\text { interactions } \\
\text { Vander Waals, and } \\
\text { Alkyl, Pi-Alkyl }\end{array}$ \\
\hline $\begin{array}{l}\text { MPI8 - } \\
\text { inhibitor }\end{array}$ & -7.7 & $\begin{array}{l}\text { Phe140, } \\
\text { Glu166, } \\
\text { Gly143, } \\
\text { Ser144, } \\
\text { Cys 145, } \\
\text { Gln189, } \\
\text { His163, } \\
\text { Thr190 }\end{array}$ & $\begin{array}{c}\text { Tyr54, } \\
\text { Asp187,Arg188, } \\
\text { Leu167, } \\
\text { Gln192,His164, } \\
\text { His172, Leu141, } \\
\text { Asn142, Met165 and } \\
\text { His41, Met49 }\end{array}$ \\
\hline $\begin{array}{l}\text { Alpha- } \\
\text { Amyrin }\end{array}$ & -7.6 & Thr24 & $\begin{array}{l}\text { Asn142, Gly143, } \\
\text { Glu166, Gln189, } \\
\text { His41, Met49, Thr25 } \\
\text { and Met165 }\end{array}$ \\
\hline $\begin{array}{l}\text { Gamma- } \\
\text { Sitosterol }\end{array}$ & -6.7 & - & $\begin{array}{l}\text { Ser144, His163, } \\
\text { Asn142, Phe140, } \\
\text { Leu141, Glu166, } \\
\text { His164, Asp187, } \\
\text { Tyr54, Arg188, } \\
\text { Gln189, Pro52 and } \\
\text { Met49, Met165, His41 }\end{array}$ \\
\hline $\begin{array}{c}\text { Alpha } \\
\text { Cubebene }\end{array}$ & -5.7 & - & $\begin{array}{l}\text { Tyr54, Asp187, } \\
\text { Gln189, Cys145 and } \\
\text { Cys44, Met165, } \\
\text { Met49, His41 }\end{array}$ \\
\hline Loliolide & -5.7 & Met49 & $\begin{array}{c}\text { His164, Pro52, Tyr54, } \\
\text { Gln189, Arg188, } \\
\text { Asp187 }\end{array}$ \\
\hline Humulene & -5.7 & & $\begin{array}{l}\text { Tyr54, Pro52, Cys145, } \\
\text { His164, Glu166, } \\
\text { Asp187, Arg188, } \\
\text { Gln189 and Met165, } \\
\text { Met49, His41 }\end{array}$ \\
\hline
\end{tabular}

Although the bonded and non-bonded interactions of these compounds vary, the crucial interaction residues mediated by the inhibitor MPI8 were maintained by these phytochemicals, indicating that these compounds could act asSARS-CoV-2 Main protease inhibitors with similar efficacy to MPI8. This could elucidate that why extracts that constitute these phytochemicals are active. This could explain that's why the extracts that constitute these compounds are active.

\section{Conclusion}

Various Phytoconstituents of the medicinal herb of Aegle marmelos (Vilvam) such as Methyldodecanol, Carene, Alpha-Amyrin, AlphaCubebene, Cinnamamide, D-Limonene, Gamma- Sitosterol, Heneicosane, Humulene, Isoledene, Linalyl Acetate, Loliolide, OXylene, Tridecane were selected for docking from the leaf extract of the medicinal herb Aegle marmelos (Vilvam). 3D structures of 14 bioactive were taken from PubChem structures revels significant binding against receptor Spike protein of COVID-19. If in silico investigations are confirmed with antiviral activity trials, it could be a future treatment against this coronavirus infection. In addition, preclinical and clinical research must be carried out to evaluate the exact mechanism. India is a developing country with a moderate rate of economic growth. This simple herb is usually always available at Shiva temples. This simple herb will save many poor individuals from this pandemic illness if its usefulness is proven.

\section{Acknowledgement}

We, authors, acknowledge Mr.Navaneeth MBA for his guidance and support for this study.

\section{Conflict of Interest}

We announce that there is no conflict of interest in this study.

\section{Sources of funding}

This study earned no particular grant from public, private, or non-profit funding organizations.

\section{References}

1. Chen Y, Liu Q, Guo D. Emerging coronaviruses Genome structure, replication, and pathogenesis. J Med Virol. 2020; 92(4):418-423

2. V'kovski, P, Kratzel A, Steiner S. et al. Coronavirus biology and replication: implications for SARSCoV-2. Nat Rev Microbiol. 2021; 19: 155-170. https://doi.org/10.1038/s41579-020-00468-6

3. NikilNiva J, Sasirekha R, Anbu N, Shree Devi MS, Sathiyarajeswaran P. In Silico Docking Analysis of Poly Herbal Formulation Aadathodai Kudineer used in Siddha medicine in inhibiting Main Protease and ACE2 Receptor Spike protein SARS$\mathrm{CoV}-2$. International Journal of Ayurvedic Medicine.2021; 11 (4):765-772.

4. Sohrabi C, Alsafi Z, O’Neill N, Khan M, Kerwan A, Al-Jabir A, Iosifidis C, Agha R. World Health Organization declares global emergency A review of the 2019 novel coronavirus (COVID-19). International Journal of Surgery. 2020; 76:71-76

5. https://www.mygov.in/corona-data/covid19statewise-status/

6. Rutwick Surya U, Praveen N. A molecular docking study of SARS-CoV-2 main protease against phytochemicals of Boerhavia diffusa Linn. for novel COVID-19 drug discovery. Virusdisease. 2021; 32(1):1-9. doi: 10.1007/s13337-021-00683-6.

7. Thillaivanan S, Velvizhi I, Sathiyarajeshwaran P, Susikannamma S, Parthiban P, Ganesh S,

Shanmugasundaram A. An Open-Label Clinical Trial to Evaluate the Safety\& Efficacy of Siddha Sastric Medicines - Fixed Regimen in COVID-19 Positive Asymptomatic, M i $1 \mathrm{~d}$ or Moderate cases - A Pilot Study. International Journal of Ayurvedic Medicine. $\quad 2021 ; 12$ (2):347-352.

8. Kalaiarasi R, Jeeva Gladys, R, Elangovan, S, Soundararajan, DK, Mubarak H, and

Kanakarajan A. A Combination of Nilavembu Kudineer and Adathodai Manapagu in the management of Dengue Fever. International Journal of Current Research. 2013; 5(4): 978-981. 
9. Rathinam S, Muthiah K, Parameswaran S, Tamilarasan K, Selvarajan E, \& Ayyasamy U. Analogy of Kaba Suram with COVID-19 Symptoms - A Siddha Literature Review. International Journal of Ayurvedic Medicine. 2020; 11(4), 616-621. https://doi.org/ 10.47552/ijam.v11i4.1674

10. Sumathi S, Swathi K, Suganya K et al. A broad perspective on COVID-19: a global pandemic and a focus on preventive medicine. Tradit Med Res. 2021; 6(2):12. doi: 10.12032/TMR20201018202.

11. Murugesa mudaliyar KS. Siddha Materia Medica (Medicinal Plants Division). $8^{\text {th }}$ edition,Chennai: Directorate of Indian Medicine \& Homeopathy. 2006: 519-522.

12. Veerappan Arul, Shigeru Miyazaki, Renganathan Dhananjayan. Studies on the Anti- inflammatory, Antipyretic, and Analgesic properties of the leaves of Aegle marmelos Corr. J Ethnopharmacol. 2005; 96(1-2):159-63. doi: 10.1016/j.jep.2004.09.013.

13. Badam L, Bedekar S, Sonawane KB, Joshi SP. In vitro antiviral activity of bael (Aegle marmelos Corr) upon human coxsackieviruses B1B6. J Commun Dis. 2002; 34(2): 8899.

14. Balasubramanian G, Sarathi M, Kumar SR, Hameed AS. Screening the antiviral activity of Indian medicinal plants against white spot syndrome virus in shrimp. Aquaculture. 2007; 263(1-4):15-19.

15. Atul NP, Nilesh VD, Akkatai AR, Kamlakar SK. A review on Aegle marmelos: A potential medicinal tree. Int Res J Pharm. 2012; 3(8):86-91.

16. Vyas A, Bhargava S, Bhargava P, Shukla S, Pandey $\mathrm{R}$, Bhadauria R. Evaluation of the antipyretic potential of Aegle marmelos (L.) Correa leaves. Orient J Chem. 2011; 27 (1):253257.
17. Benni JM, Jayanthi M, Suresha R. Evaluation of the anti-inflammatory activity of Aegle

marmelos (Bilwa) root. Indian J Pharmacol. 2011; 43(4):393-397.

18. Nugroho AE, Riyanto S, Sukari MA, Maeyama K. Effects of aegeline, the main alkaloid of A egle marmelos Correa leaves, on the histamine release from mast cells: Pak J Pharm S c i. 2011 ; 24 (3): 359-367.

19. Yang KS, Ma XR, Ma Y et al. A Quick Route to Multiple Highly Potent SARS-CoV-2 $\mathrm{M}$ a i n Protease Inhibitors. Chem Med Chem. 2021; 16(6): 942-948. doi: 10.1002/cmdc.202000924.

20. Helen M Berman, John Westbrook, Zukang Feng, Gary Gilliland, TN Bhat, Helge

Weissig, Ilya N. Shindyalov, Philip E. Bourne, The Protein Data Bank. Nucleic Acids

Research. 2000; 28(1):235-242. https://doi.org/ 10.1093/nar/28.1.235.

21. Trott O \& Olson AJ. AutoDockVina: improving the speed and accuracy of docking with a n e w scoring function, efficient optimization, and multithreading. Journal of computational chemistry. 2010 ; 31(2): 455-461.

22. Morris, GM, Huey R., Lindstrom W, Sanner MF, Belew RK, Goodsell, DS Olson AJ. A u t o D o c k 4 and AutoDockTools4: Automated docking with selective receptor flexibility. Journal of computational chemistry. 2009; 30(16):2785-2791.

23. Olufunke M D. Essential oils from aerial, seed, and root of Nigerian Asystasia gangetica. Essent J. Oil-Bearing Plants. 2011; 14(5): 582-589. https:// doi.org/10.1080/0972060X.2011.10643975.

24. Daina, A., Michielin, O. \& Zoete, V. SwissADME: a free web tool to evaluate pharmacokinetics, drug-likeness and medicinal chemistry friendliness of small molecules. Sci Rep .2017; 7: 42717. https://doi.org/10.1038/srep42717. 